\title{
Socializing pre-service teachers into mathematical discourse: the interplay between biliteracy and multimodality
}

Alberto Esquinca

\author{
Correspondence: aesquinca@utep. \\ edu \\ 500 W. University Ave. EDUC 601, \\ El Paso, TX 79968, USA
}

\begin{abstract}
This is a study of the development of mathematical discourse among biliterate preservice teachers. Mathematical discourse is a multimodal discourse, in which mathematical meaning is constructed through multiple semiotic systems.

Furthermore, in the continua of biliteracy framework, being able to construct meaning while drawing on multiple points of the continua promotes biliterate development. However, the ways in which biliterate pre-service teachers draw on both multimodality and biliteracy to develop mathematical discourse is a rarely researched topic. In this case study, data were gathered from participant-observation of a college mathematics class for pre-service teachers, participant interviews and small group study sessions at a public university on the U.S./Mexico border. A major component of the class was communicating mathematics meaningfully. Participant structures in which writing mediated communication were identified. In the classroom, students communicated with a variety of audiences in English, and through their participation students became socialized into mathematical discourse. However, it was in study sessions outside the classroom where students were able to draw on their biliteracy and multimodal resources more fully. In study sessions, participants used multimodality and biliteracy to engage with one another while at the same time forging an incipient identity as bilingual/biliterate teachers. Implications for teaching bilingual/biliterate college students are offered.
\end{abstract}

Keywords: Mathematical discourse, Multimodality, Biliteracy, Pre-service teachers

\section{Background}

To communicate using mathematical discourse is crucial in learning mathematics. According to mathematician [Anna Sfard (2008)], to learn mathematics is to learn its discourse. Although mathematical discourse is not typically taught directly, in some pedagogical approaches students are able participate in dialogue in which they have to use it, i.e., students are socialized into and through mathematical discourse ([Ochs, 1988,Duff, 2010]). Through participation in oral/literate social interactions, learners may become socialized in the midst of problem solving activities into using mathematical discourse. Symbolically mediated participation in discourse structures serves to socialize learners into the discourse of mathematics.

Developing the discourse of mathematics is crucial for pre-service teachers. However, little is known about the process by which pre-service teachers become socialized into

(c) 2012 Esquinca; licensee Springer. This is an Open Access article distributed under the terms of the Creative Commons Attribution License (http://creativecommons.org/licenses/by/2.0), which permits unrestricted use, distribution, and reproduction in any medium, provided the original work is properly cited. 
mathematics discourse. Even less is known about how bilingual/biliterate pre-service teachers develop mathematical discourse, since much research focuses on "mainstream," monolingual learners and has been argued to view bilingual learners in a deficit perspective ([Moschkovich, 2010]).

Drawing academic (discourse) socialization ([Schieffelin 1990,Duff, 2010]) and biliteracy ([Hornberger \& Skilton-Sylvester 2003]), I characterize the socialization of bilingual/biliterate pre-service teachers into the multimodal discourse of mathematics ([O'Halloran, 2005]). In this case study of three pre-service teachers on the U.S./Mexico border, the research questions are the following.

- What are classroom oral and written activities in which pre-service teachers participate (especially those unique to mathematics)?

- What multimodal literacy events occur inside and outside the classroom?

- What patterns of interaction (including language choices) emerge inside and outside the classroom?

- How does the goal of becoming a teacher impact socialization into the discourse?

I identify and analyze multimodal communicative practices in a mathematics classroom, where instruction was delivered in English, that promoted in-depth discussions around mathematical problems. Because of the focus on bilingual/biliterate learners, I also analyze data gathered outside the classroom in study groups, which were conducted in Spanish and English. In this way, a more complex account of the experiences of pre-service teachers' socialization into and through mathematical discourse is presented. Thus, this account shows the interplay between participants' linguistic repertoire and multiple modes of making meaning [(García et al. 2007)] in the midst of preparing to become teachers in a mathematics course for pre-service teachers.

\section{Setting}

The 2,000 mile long U.S./Mexico border brings together multiple national, state and county boundaries, and 15 pairs of sister cities, including El Paso/Ciudad Juárez. In sister cities along the border, many inhabitants are educated in both cities, as evidenced by the millions of yearly border crossings at international checkpoints. It is common for students to live on one side of the border and work and/or study on the other side. Even infrequent crossers can maintain strong personal and professional relationships on both sides of the border.

This case study was conducted at a public university on the US/Mexico border. About ten percent of the student population is Mexican, including those who cross international checkpoints daily to arrive in class. However, the majority of university students are Mexican American, and they speak Spanish at home.

\section{Participants}

Although the majority of students at the university are U.S.-educated, many students live and have been educated in Mexico. Participants in the study are included in the latter group, having been educated in Mexico, at least until the tenth grade. One participant moved to the U.S., but visits weekly and the other two commute daily. All are seeking to become trained and certified as middle school teachers.

Three participants, all of whom were pre-service teachers, were invited to be part of the study based on their occasional use of Spanish in the mathematics classroom. All 
three attended ESL classes in the U.S. in high school or college, and they are identified here with pseudonyms. Laura, a Bilingual Education major who declared her proficiency in English to be developing, attended ESL classes at a local community college. Yolanda, a Special Education major, also attended ESL classes at the community college, and said that her second language was developing. Betty is a Mathematics and Science major who attended high school in the U.S., and who expressed confidence in her second language proficiency, adding that she wanted more opportunities to practice it.

\section{Classroom setting: a mathematics course for future teachers}

This case study of border bilingual/biliterate pre-service teachers' socialization into the discourse of mathematics was conducted as participants were enrolled in a mathematics course for pre-service teachers. Like all pre-service teachers seeking to become certified to teach in the middle grades, these students are required to take a course entitled Conceptual Algebra (a junior-level course), which prepares students to develop mathematical content. According to the undergraduate catalog, Conceptual Algebra is an inquiry-based course covering mathematical concepts including ratio, proportion, functions, algebra and geometry with an emphasis on reasoning and mathematical thinking. The course is intended to develop a) attention to the meaning of symbols and numbers, b) analysis of problem situations, and c) hypothesizing and justifying mathematical solutions.

One of the main goals of the course is for students to develop mathematical concepts to such an extent that it is possible for them to converse about them. According to the syllabus, the course is organized around problem-based activities. Mathematical reasoning and mathematical communication are promoted through problems that require oral discussion and writing. Because of the focus of the study (development of mathematical discourse among bilinguals), I considered a course on developing communication (with frequent opportunities for students to discuss) to be a suitable research site.

\section{Developing mathematical discourse}

Mathematics educators have proposed a situated, sociocultural perspective on the discourse of mathematics ([Moschkovich, 2002]). [Sfard (2008)] argues that to know mathematics is to know its discourse. Drawing on sociocultural theory ([Vygotsky, $1978])$, as well as new literacy studies [(Gee, 1996)], Sfard argues that communicating with and through mathematical discourse is central to learning mathematics. "Some familiarity with the objects of the discourse seems a precondition for participating, but at the same time participation in the discourse is a precondition for gaining this familiarity" ([Sfard, 2008], p. 161). She further argues that what distinguishes literate mathematical discourse from everyday mathematics is its mediation through multimodality. Whereas everyday mathematics can use objects to mediate interaction, in literate, school-like mathematics, symbolic and visual representations mediate interaction. In addition to its reliance on symbolism to mediate, [Sfard (2008)] adds the use of dense mathematical vocabulary, the use of mathematical narratives and of mathematical routines as features of mathematical discourse. 
[Sfard (2002)] has made the argument that students of mathematics must "become participants of the new discourse before they can fully appreciate its advantages" (p. 13). Similarly, in the language socialization tradition ([Ochs, 1988,Schieffelin 1990]), becoming a member of community is achieved discursively. "Socialization is an interactive process between knowledgeable members and novices (children) who are themselves active contributors to the meanings and outcomes of interactions with others" ([Schieffelin 1990], p. 17). Interaction with more knowledgeable dialogue partners, such as teachers, achieves socialization since interaction is co-constructed in a moment-by-moment basis. The notion of socialization has been used in various contexts, including with adult learners developing academic discourses (Duff, [2007,2010]). In this study, learners interacted using mathematical discourse and, through that interaction, they receive feedback from the teacher and from their peers. Thus, in this view, mathematical discourse is not limited to using technical, dense vocabulary but "...styles of meaning and modes of argument...and of combining existing elements into new combinations" ([Halliday, 1978], p. 195-196).

According to ([Duff 2010], p. 173), academic (discourse) socialization theory also considers culturally specific ideologies. These can include ideologies about how to use language, how to show respect or scholarly behavior and decorum in the classroom. Learners can internalize, challenge or resist these ideologies. [Ochs and Schieffelin (2008)] add that individual socialization trajectories are "complexly structured by webs of social and economic institutions, public and domestic systems of control, practices, identities, settings, beliefs, meanings, and other forces" (p. 8). Individuals are agents in their socialization, and they can shape, resist or transform the situation into which they are being socialized. Thus, socialization is not unidirectional, but bidirectional, though power and knowledge asymmetries are a key constraint.

[Lemke (1990)] has shown, literacy practices in science, mathematics and technology are not value-free. Teachers and learners make use of discourse norms in bids to be recognized as a member of a discourse community, such as the avoidance of colloquialisms, personification and narrative or the use of technical terms over everyday terminology. Developing mathematical discourse is not limited to words and phrases, but becoming situated in relation to others. As [Gee (2005)] writes "a social language is a way of using language so as to enact a particular socially-situated identity and carry out a particular socially-situated activity" (p. 20).

\section{Multimodality in mathematical discourse}

In mathematical discourse, meanings are constructed using a range of meaning-making resources and in more than one modality (Schleppegrell, [2007,2010,Solomon, 2009, Morgan, 1998,Moschkovich, 2010,Gutiérez et al. 2010]). Multiple modes are used to construct meaning in mathematical discourse. Drawing on Halliday's register theory ([Halliday \& Matthiessen, 2004]), writers have proposed that language varies along a mode continuum. [Eggins (2004)] notes that the role that language itself is playing in the interaction is a way to determine where in the mode continuum the communication falls. When language itself contextualizes interaction, it is more written-like, but where language is another element and physical or visual cues accompany language it is more speech like. Mathematical discourse is multimodal because communication draws along different points in the continuum, even in face-to-face communication. 
More recently, researchers have proposed a variety of modes. For instance, [Kress (2010)] proposes a full range of modes including image, writing, layout, music, gesture, speech, moving image, soundtrack and 3D objects. [Veel (1999)] characterizes mathematical discourse as one in which oral language modes is accompanied by visual and symbolic representations modes.

Researchers working within an SFL theoretical framework, ([O'Halloran, 2005,Lemke, 2003,Schleppegrell, 2007]), have shown how multiple meaning-making systems are used in mathematical texts. [O'Halloran's (2005)] analysis of mathematical texts demonstrates how three semiotic systems, mathematical symbolism, visual display, and natural language together construct mathematical meaning in ways that natural language alone does not. For instance, [O'Halloran (2005)] shows that mathematics argumentation in texts typically unfolds as problem-solution. In order to solve the problem, writers of mathematics will arrange mathematical symbols in patterned ways so that they encode a limited range of meanings. In addition, the writer must also include visual images, such as statistical graphs, geometric diagrams, and other kinds of drawn or computer-generated visual displays. Through these visual displays, the writer illustrates mathematical meanings in a space-time format. However, mathematical symbolism and visual display may be relatively limited in functionality, and the writer must accompany the symbols and visual display with natural language. Natural language functions serves to disambiguate and clarify meanings when the meaning potential of mathematical symbolism and visual display are exhausted.

\section{Bilingualism/biliteracy and mathematical discourse}

Although there is growing interest among mathematics educators about multilingualism and its interaction with learning mathematics, [Moschkovich (2010)] has noted, "research has not yet seriously considered any possible advantages of bilingualism for mathematics learning" (p. 11), and instead research can sometimes situate bilingual learners in a deficit perspective. This is sometimes evident, she argues, in research that positions learners as lacking abilities or in research which assumes monolingualism. In addition, I argue that research on the question of the associated advantages of bilingualism on mathematical learning could benefit from drawing on methodologies and theoretical insights from the fields of sociolinguistics and linguistic anthropology.

For instance, one insight is that educational program options available to multilingual students impact their development of bilingualism/biliteracy. As [Martin-Jones (2007)] argues, educational programs serve "as a means of assigning value to language and literacy resources, and at the same time, as a means of regulating access to them" (p. 163). Thus, whether multilinguals are in a program that fosters their multilingualism will impact the range of data to be gathered in research investigations. In this vein, research by [Moschkovich (2002)] and [Zahner and Moschkovich (2011)] in dual language programs has shown that bilingual students doing mathematics are able to use their languages as resources to make meaning across languages. [Moschkovich (2002)] shows how bilingual students participate in discourse practices, such as describing a pattern or clarifying a description. Other researchers have also conducted investigations into programs, including after school programs, that foster bilingualism (Turner, Gutiérez et al. 2010; [Morales et al. 2011]). 
However, many researchers have conducted research in majority language programs in which learners use both languages to varying degrees ([Barwell, 2009, Chval \& Khisty, 2009,O'Rode 2011,Acosta-Iriqui et al. 2011]). Much of the research on multilingualism and mathematics learning takes place in sites in which bilinguals are in classrooms where the curriculum is delivered in the majority language, even when teacher and students share another language ([Setati et al. 2002,Setati, 2005]). This could reflect the regrettable lack of programs that foster bilingualism, but it could also suggest a theoretical and/or methodological oversight, as [Moschkovich (2007)] notes.

Another insight is that bilinguals have multiple domains of language use $\left({ }^{\mathrm{Q} 3}[\right.$ Valdés, Brooks and Chavez, 2003]) and thus when conducting research on bilinguals, it is important to determine whether data is being gathered when speakers are in a monolingual domain or in a bilingual domain [(Grosjean, 2008)]. If they are in a monolingual domain, such as an English-Only classroom, they may be less likely to exhibit bilingual behavior such as code-switching or translanguaging [(García, 2009)]. Moreover, situational factors such as the interlocutor, the place or the topic might trigger a switch into one language or the other. For instance, bilingual writers may switch to the language of instruction (often the majority language) when writing an academic topic. In Barwell's ([2009]; 2005) investigation, bilingual students wrote mathematical word problems in English monolingual mode. In contrast, in another study on bilingual students writing word problems, data are reported bilingually [(Esquinca, 2011)]. In that study, a group of bilingual writers wrote using both languages during the entire writing session (including extensive use of translanguaging ${ }^{\mathrm{Fn} 1}$ ), suggesting that considering situational factors can have an impact whether the researcher will obtain data in monolingual or bilingual mode.

Furthermore, bilingualism/biliteracy researchers have also pointed out how multiple factors impact the development of biliteracy. [Hornberger and Skilton-Sylvester 2003] propose an ecological framework for its study, the Continua of Biliteracy framework. It includes multiple nested continua grouped in terms of contexts, development, content and media. The authors propose multiple continua in order to bring awareness to the multiplicity of factors that impact biliteracy, and to aid researchers to focus on factors while being aware of the intervening factors that may also be at play.

The most relevant continua for the present analysis are grouped those in the context of bilitearcy category. The micro to macro continuum captures the ideological and political factors impacting the development of biliteracy at the broadest level as well as at the local, classroom level context. The oral/literate continuum captures [Hornberger's 1990] definition of biliteracy "any and all instances in which communication occurs in two (or more) languages in or around writing” (p. 213). The definition opens up instances of biliteracy to those in which oral interactions around writing take place. In this investigation, multimodality in mathematics, including written visual prepresentations, is linked to the development of biliteracy in college mathematics education. Literacy events [(Heath, 1982)] could thus include oral interactions around written mathematical representations. Thirdly, the bi(multi)lingual to monolingual continuum refers to bilinguals' domains of use, as noted above. Here, literacy events are studied inside the classroom, an English domain, and in small group study sessions, a bilingual domain. Thus, multiple modalities and ways of making meaning in writing are flexible 
enough to be used across situational and linguistic contexts, and each of these factors are part of the ecological context for socializing learners into mathematical discourse.

\section{Results: multimodality and biliteracy in college mathematics}

Socialization into the discourse of mathematics involves two crucial factors: participating in its discourse structures and utilizing its mediating tools ([Sfard 2002]). In the setting I investigated, these two factors became apparent through participant-observation. Each class meeting was organized around a recurrent cycle of literacy events in which oral interactions were mediated by written visual and symbolic representations. A cycle of participant structures in which posing problems, discussing them and presenting solutions took place in each class I observed. The professor initiated the cycle by posing problems, and students presented, discussed and solved the problems, and sometimes questioned the meaningfulness of alternative solutions. This cycle of literate participant structures is represented in Figure 1.

Secondly, multimodality was also a fundamental factor in socializing students into mathematical discourse. When the professor posed problems, problems were usually printed on handouts that made use of the multimodality (including word problems, diagrams, and topics for homework assignments). The professor read aloud the problem or students would read the problem individually and begin working out the problems in writing on their notebooks. As students worked alone, they would always

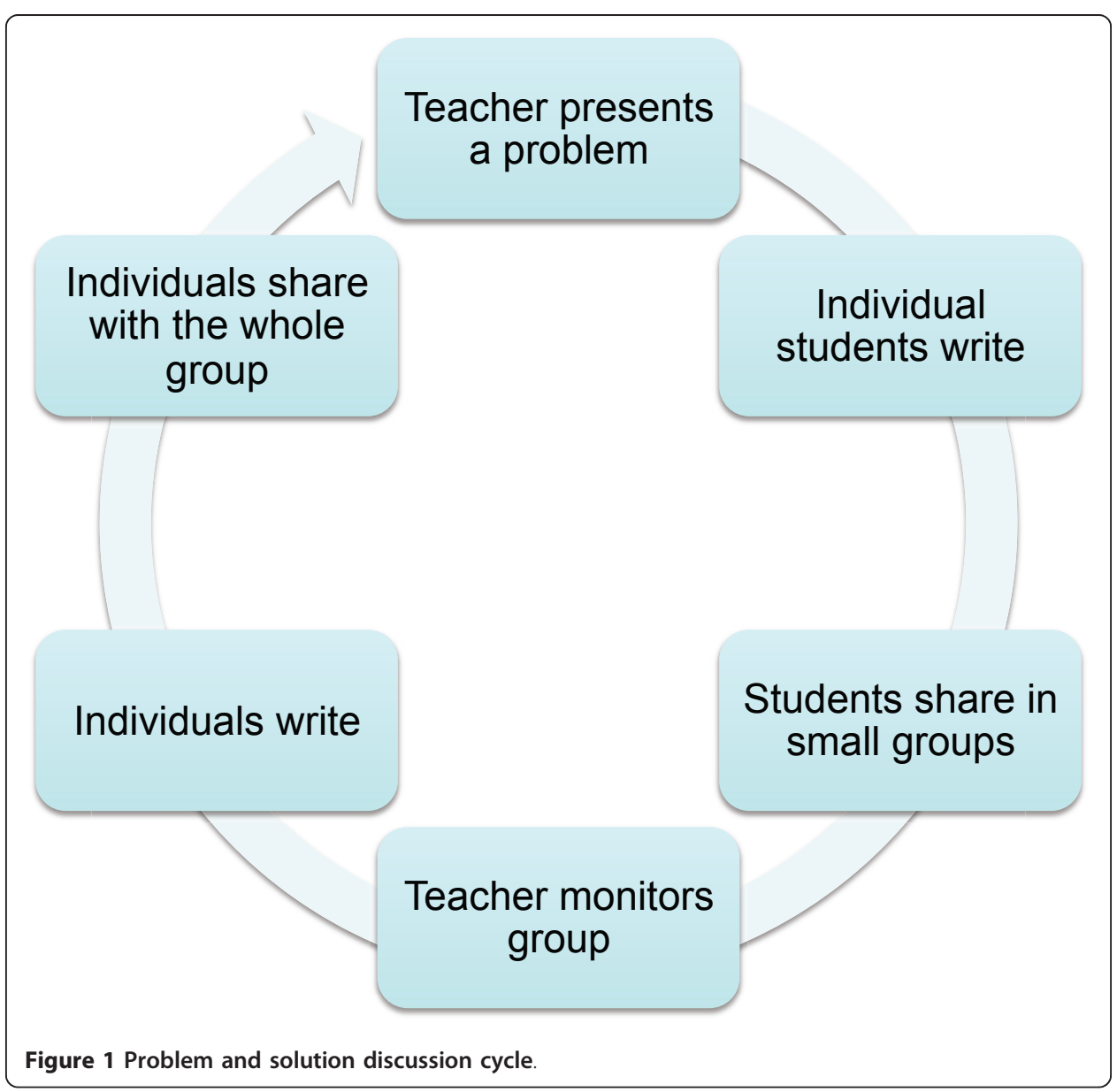


write solutions on their paper, which they would use to present their solutions. Field notes show no instances of students not writing on paper to solve their problems. After approximately five or six minutes of individual work, students would share their solutions with those in their group.

Discussions and dialogue around mathematical word problems took place in a variety of literacy events. Each event varied depending on factors including participants, typical modalities, and communicative purpose (in part determined by the place along the cycle in which it occurs). The cycle is further specified in Table 1 below.

The professor designed classroom activities that made it possible for students to communicate their thinking with others, as stated in the syllabus. Participating in these structures made it possible to socialize students with students taking up some of these practices outside the classroom. Moreover, the values that were embodied in classroom discourse socialization activities ran counter to the ideology that all students solve problems in the same way, or at the same pace ([Prediger, 2005]). Instead, the professor continuously asked the class of future teachers to listen to different ways to solve mathematical problems and try to see the meaningfulness in different solutions. Further, it was by sharing different solutions that students could gain different perspectives on learning mathematics meaningfully. In what follows, I focus on two multimodal literacy events, Small Group Sharing and Whole Group Sharing in order to discuss some of the ways they were taken up outside the classroom.

\section{Small group sharing}

Small Group Sharing was a participant structure in which the values of cooperation and diversity were upheld ([Prediger, 2005]). During these events, individual students could demonstrate how they arrived at the problem to their peers and listen to different ways of solving problems. In these events, students began to see that people in their group could have arrived at a solution differently, and that it could make sense. In addition, students who were not able to solve the problem could ask the group for help. These events would unfold as follows. After a problem had been assigned,

Table 1 Overview of participant structures

\begin{tabular}{|c|c|c|c|c|c|c|}
\hline & $\begin{array}{l}\text { Presenting } \\
\text { problem }\end{array}$ & $\begin{array}{l}\text { Individual } \\
\text { writing }\end{array}$ & $\begin{array}{l}\text { Small } \\
\text { Group } \\
\text { Sharing }\end{array}$ & $\begin{array}{l}\text { Teacher } \\
\text { Monitoring }\end{array}$ & $\begin{array}{l}\text { Student } \\
\text { writing }\end{array}$ & $\begin{array}{l}\text { Student to } \\
\text { whole group, } \\
\text { mediated by } \\
\text { teacher }\end{array}$ \\
\hline Participant(s) & $\begin{array}{l}\text { Teacher } \\
\text { and } \\
\text { whole } \\
\text { class }\end{array}$ & $\begin{array}{l}\text { Individual } \\
\text { students }\end{array}$ & $\begin{array}{l}\text { Students } \\
\text { in small } \\
\text { groups }\end{array}$ & $\begin{array}{l}\text { Teacher and } \\
\text { small group }\end{array}$ & Individual & Whole class \\
\hline $\begin{array}{l}\text { Purpose of } \\
\text { communication }\end{array}$ & $\begin{array}{l}\text { To assign } \\
\text { problem }\end{array}$ & $\begin{array}{l}\text { To work } \\
\text { out } \\
\text { problems in } \\
\text { preparation } \\
\text { for next } \\
\text { event }\end{array}$ & $\begin{array}{l}\text { To share } \\
\text { solutions }\end{array}$ & $\begin{array}{l}\text { To give } \\
\text { feedback to } \\
\text { small groups }\end{array}$ & $\begin{array}{l}\text { To work } \\
\text { out } \\
\text { problems in } \\
\text { preparation } \\
\text { for next } \\
\text { event }\end{array}$ & $\begin{array}{l}\text { To share } \\
\text { solutions and } \\
\text { discuss } \\
\text { meaningfulness }\end{array}$ \\
\hline Modes & $\begin{array}{l}\text { Students } \\
\text { read } \\
\text { and/or } \\
\text { listen; } \\
\text { teacher } \\
\text { talks }\end{array}$ & $\begin{array}{l}\text { Individual } \\
\text { students } \\
\text { write } \\
\text { multisemiotic } \\
\text { text }\end{array}$ & $\begin{array}{l}\text { Students } \\
\text { speak } \\
\text { mediated } \\
\text { by } \\
\text { multisemiotic } \\
\text { text }\end{array}$ & $\begin{array}{l}\text { Teacher and } \\
\text { small groups } \\
\text { talk, } \\
\text { mediated by } \\
\text { multisemiotic } \\
\text { text }\end{array}$ & $\begin{array}{l}\text { Students } \\
\text { write } \\
\text { multisemiotic } \\
\text { text }\end{array}$ & $\begin{array}{l}\text { Individual } \\
\text { students and } \\
\text { teacher talk; } \\
\text { students } \\
\text { comment; } \\
\text { mediated by } \\
\text { multi-semiotic } \\
\text { text }\end{array}$ \\
\hline
\end{tabular}


students began working individually. After a few minutes, one student would turn to others in the group to ask: "How did you do it?" Students would then position their bodies to be in view of the written representation to be shared. Written representation mediated their oral interaction, and events were multimodal.

Written symbolic representation accompanied the graphic representation, and students would use oral language to go back and forth about each solution. For instance, during the seventh week of the semester, a notable interaction took place. The professor distributed a handout that read: "\#1 A fifth grader asked you what $1 / 3 \div 4 / 5$ means. How would you help him understand $1 / 3 \div 4 / 5$ meaningfully?" After a few minutes of individual work, some students seemed stuck. The professor said "Draw picture? Ok, draw a picture and then discuss with your group." After some additional silent work, Betty, one of the participants, initiated the small group sharing when she asked a group mate (a non-participant), "How did you do it?" Betty also answered the question, saying that she divided the whole by one-third, and then divided that third further, into fifths. Figure 2 was produced, with the shaded area showing the result of the operation, and Betty said "Take one-third and divide it in five pieces."

In the example, the oral mode was spoken in English. Meaningfully explaining the division of fractions in this case draws on all three semiotic systems ([O'Halloran, 2005]). Betty used a visual representation, accompanied it with symbolic representation, and used natural language to present the solution. Her explanation in the oral mode was accompanied by the mediation of a representation in the written mode.

The example also serves to illustrate how Betty positioned herself in regards to mathematical discourse in ways that could even run counter to the values being promoted in the course. Betty's understanding of mathematics is strongly shaped by her prior mathematics education in Mexico. The daughter of a Mexican teacher, Betty tutored her mother's students as well as adult women. For her, Small Group Sharing and Whole Group Sharing was unnecessary. She sometimes complained of "constantly having to share" in class. She considered Small Group Sharing to be a time-consuming nuisance, and seemed to resent having to explain concepts to others. Worse, when asked if she would use some of the literacy events that she experienced in the class or ask students to work in small groups, she answered that she would never do it. En grupos jamás; yo estoy en contra de los grupos" ("Never in groups; I'm against groups."). Like her, other students would sometimes say loudly that they wished that the professor would just say how to solve a problem instead of asking students to share, that they did not see the point of constantly drawing or of small group work. The professor, however, would often express values about cooperation and diversity of solutions, especially in the literacy event presented next. Socialization into mathematical
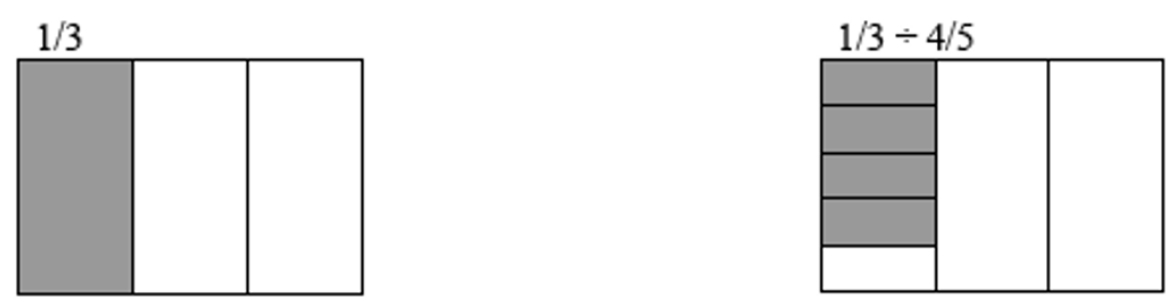

Figure 2 Betty's Small Group Sharing Graphic. 
discourse does not mean that participants were passive receptors. Rather, they might even contest it, as Betty does.

\section{Whole group sharing}

Whole Group Sharing, which like, Small Group Sharing, was also multimodal, took place almost at every class meeting. Participants used both oral and speech modes, and used the three semiotic systems to write-on the board. It was usually the culmination of a problem-solution cycle, as summarized in Table 1 and Figure 1 above. The event was crucially different from Small Group Sharing in that while all students had access to sharing in groups, not all students shared in front of the whole class. As noted before, presenters were often selected by their small group or invited by the professor to present. For each problem, two or three students presented alternative solutions.

In addition to the diversity of mathematical solutions, a value or idea promoted in this event was that mathematical representations should be meaningful. The professor discussed the meaningfulness of each solution, and asked the whole class to give their point of view about the merits of each solution. During these events, students shared diverse ways to solve a problem, and it was important that others see and understand the reasoning behind each solution. The professor was careful to avoid discussing correctness since this might contradict the view that alternative solutions are possible.

To communicate mathematical meanings in Whole Group Sharing, students would prepare individually in the previous literacy event. They would write on the board using diverse semiotic resources. Students presented their solution by writing symbolic and visual representations, and they would rarely include words or phrases except as labels. There was no explicit instruction on how to write symbolically or how to represent visually. Once the solution display was ready, Whole Group Sharing began.

For example, during the last few weeks of class, the thirteenth week, the professor assigned the problem in Figure 3. When Whole Group Sharing began, Yolanda was the first student to present that time. Although during the semester she always worked in groups, she had never shared with the whole class. That day Yolanda began to share using multiple semiotic systems; she wrote the visual and symbolic representations on the board, leaving out the representation of the lake available in the handout, as shown in Figure 4. She represented the problem symbolically, with the following equation, 2

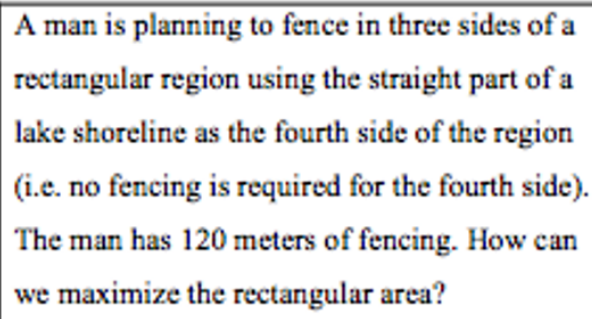

Figure 3 The professor's problem. 


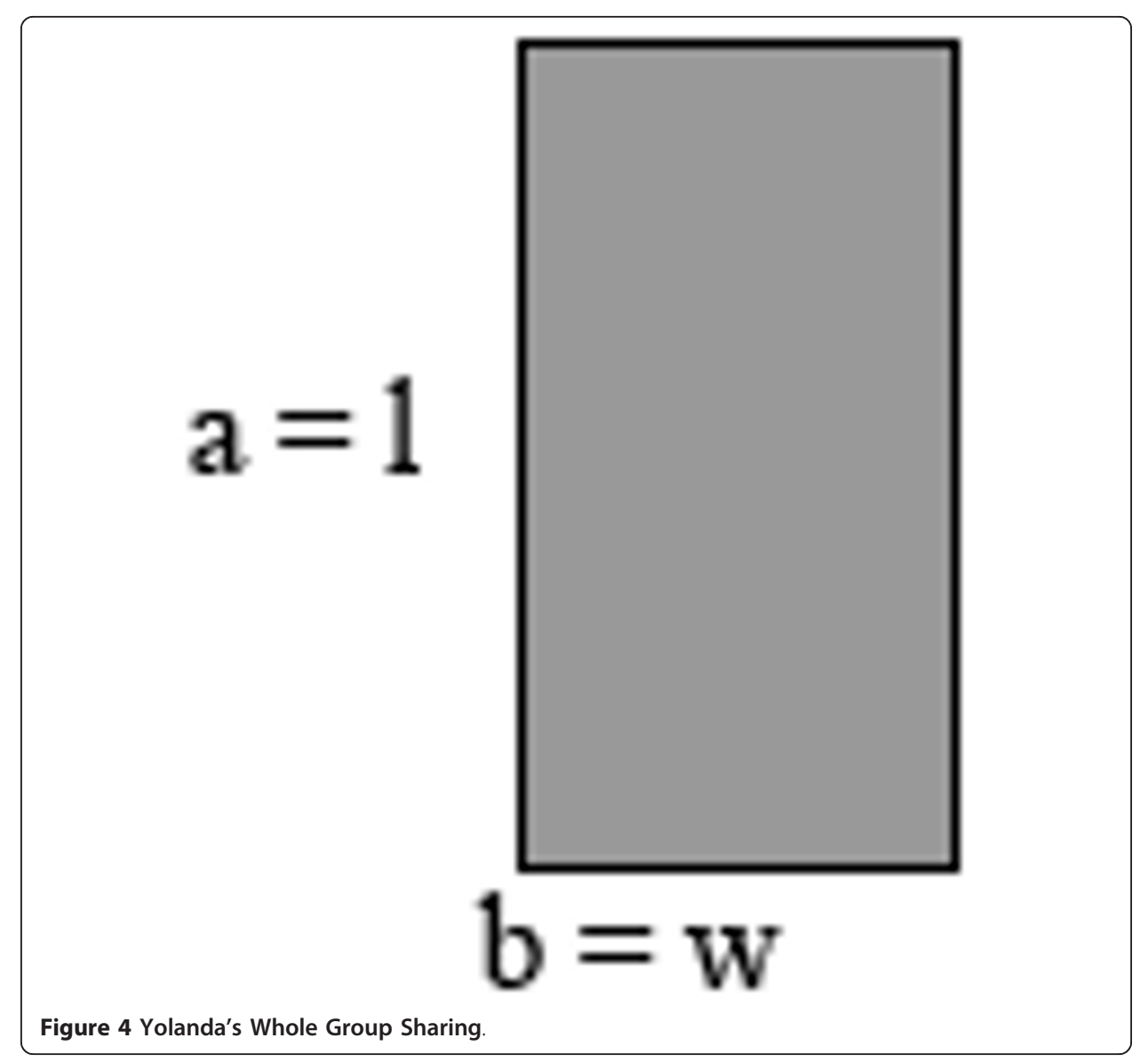

(a) $+b=120$. As the professor would later note, her equation showed that the rectangle only has three sides to be fenced (the lake impedes fencing the fourth side).

Once the professor gave her the floor, Yolanda verbally presented her solution as a step-by-step procedure mediated by multi-semiotic resources. Confidently taking control of the floor, she instructed the other students on how to solve the problem, using a soft but firm tone. In instructing her peers on how to solve the problem, she used commands (use the perimeter formula, calculate it, use the area formula, find the answer) rather than giving an account of how she did the problem (I used the perimeter formula, I calculated it, I used the area formula, I found the answer). The acts of pointing to the visual representation, using a formula, solving the equation, and giving instructions were semiotic resources at her disposal in her presentation. As she pointed to the operations on the board, she gave instructions to the class. When she finished, the professor commended her on recognizing that the rectangle only had three sides to be fenced.

Participating in Whole Group Sharing gave a student like Yolanda the opportunity share in a position of authority over the rest of the class. Students could take control of the mathematics classroom, all ears and eyes on them-similar to the traditional role of the teacher. While in that position Yolanda, who was typically shy and unsure about her mathematical expertise, could take on a new persona. She could draw on visual and symbolic meaning-making resources and take on the authoritative voice of a teacher. Placed in a position of authority in front of her peers, Yolanda took a dominant 
position over the rest of the class, and her use of linguistic, visual, and symbolic meaning-making resources strengthened her position of power in that setting. As [O'Halloran (2005)] writes, "...the dominant position of the writer is reinforced across choices for mathematical symbolism and visual display. Similarly, unequal social relations are established between the teacher and the students in the context of the mathematics classroom" (p. 70). Yolanda's use of commands, in which she gave instructions for others to follow, accompanied by her position in front of the class and her references to her visual and symbolic solution, all approximate the authoritative voice of a teacher.

Prior to that day, Yolanda only participated in Small Group Sharing although she was never absent from class and was probably the most studious participant, earning top grades in the class. Yolanda found using multimodality to be a learning tool. She noted that she learned from making drawings Cuando asi estoy haciendo los dibujos como para explicar, también al mismo tiempo yo los estoy entendiendo mejor. (When I am drawing to explain concepts, I also understand it better myself.) She also commented that she found writing she did in the class very effective to learn, but she only participated in Whole Group Sharing once. Moreover, Yolanda saw mathematical multimodality as a tool that she needed to teach mathematics inasmuch as it would need it to explain mathematics to her future students. In an interview, Yolanda said that she had learned to teach mathematics and linked the ability to multimodality. Cuando él [el profesor] nos da como los métodos y hacer los dibujos y todo, para que los niños entiendan. Sí me esta dando una idea a mi com... pues para explicarlo lo... Siento que no voy a llegar sin ninguna idea más bien ya tengo una idea de lo que voy como explicarlo por ejemplo, lo de fracciones. (I feel that the professor gives us methods and to make drawings and everything so that kids understand. It is indeed giving me an idea of how... well, to explain it. I feel that I won't arrive unprepared, but rather that I have an idea of how to explain fractions, for instance.)

In contrast, a student like Laura only ever participated in Small Group Sharing in the classroom. The contrast between Laura and Yolanda may indicate the high cognitive challenge of Whole Group Sharing. As [Bunch (2009)] has shown, presenting before the class requires that students manage a host of communicative demands, and doing so in a second language can mean an even greater effort. This is clear when considering the case of Laura, who was the only study participant who never participated in Whole Class Sharing, noting that she did not feel confident about her mathematical knowledge or about her English-language speaking skills. However, as the next section shows, Laura displayed a different side to herself in study sessions.

\section{Bilingualism and biliteracy in small group study sessions}

In the classroom, students used multimodality and oral English because it was a monolingual English space. However, observation outside the classroom indicated that their bilingual selves were perhaps not visible in the classroom. The use of oral Spanish dominated small group study sessions, and English was used minimally. They used English when they read from handouts or from the textbook, but they used mostly Spanish to speak to one another. The use of both languages might have allowed them to use a broader range of meaning-making resources. Their use of bilingualism and multimodality suggests interplay or hybridity of languages, modalities and values that flourish outside the classroom [(García et al. 2007)]. 
Dialogue during study sessions contrasted with that of the classroom. As in the classroom, a typical study session revolved around solving problems assigned by the professor. In addition, mathematical discourse was practiced drawing on multiple meaningmaking resources, including written symbolism and visual representations. However, students wrote in their notebooks in the absence of a board. Also, participation structures were not as varied as in the classroom, i.e., participants only interacted with one another. The professor was not present to orchestrate discourse into various participant structures. Still, study sessions seemed to unfold based on the various topics participants brought to the fore. As such, participants would sometimes move into different topics unrelated to the class (restaurants) or tangentially related (other mathematics teachers).

In study sessions, the value of diversity of solutions was voiced. For instance, the practice of sharing different ways to solve a problem was observed. As in Small Group Sharing, students often began study sessions finding a problem to solve. They sometimes took turns to present solutions, beginning the sharing sequence with the phrase “¿tú cómo le hiciste?” (how did you do it?). Additionally, as in Whole Group Sharing, alternative ways to solve the problem were considered side by side.

These practices were evident from the first study session conducted. At the session, students chose one of the problems assigned by the professor. "How would you help a fourth grader understand the solution for this problem? 'Juanita had mowed $2 / 3$ of the lawn and her brother Jaime had mowed 1/4 of the lawn. What part of the lawn had been mowed?" Students first took time to solve individually, and then began to share. As Betty began to present her solution, she paused for a second and said "yo buscando un pizarrón para dibujarte" (Look at me, looking for a board to draw it for you). Her statement suggests the importance of symbolic mediation to present solutions meaningfully, and also alluding to Whole Group Sharing.

As she continued, she drew a rectangle in her notebook to represent the part that Juanita mowed. Dividing the rectangle into three parts, she colored two parts, as shown in Figure 5. Next, to represent the part that Jaime mowed, she divided the whole into fourths, which results in a whole that is now divided into twelfths. She then shaded one-fourth of the pieces to show the part Jaime mowed. Finally, Betty proved the work using symbolic representation. In this move, she used symbolic representation to show that the visual and the symbolic representations concurred $(2 / 3+1 / 4=$ 11/12).

As in Small Group Sharing, different solutions could be presented. In the excerpt below, Betty shows Laura and Yolanda how to add two-thirds and one-quarter, and she manipulates symbols to convey her meaning to them. She tells them to find a common denominator, multiply the numerators, and add the fractions. However, Laura also voices an alternative solution.

The interaction most clearly illustrates Betty's making use of aspects of mathematical discourse often seen in the Whole Group Sharing, specifically the use of commands indexing authority over her peers. The sequence also shows some aspects of Small Group Sharing, specifically the peer-to-peer discussion to ask for further development. This is seen when Yolanda asks Betty to provide a full description of how she arrived at the answer in line 556 ("Do it"). The request leads Betty to position herself as a "teacher" with a sequence in which Yolanda and Laura are positioned as "pupils," 
Step 1

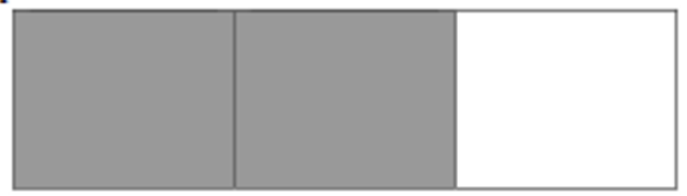

Step 2

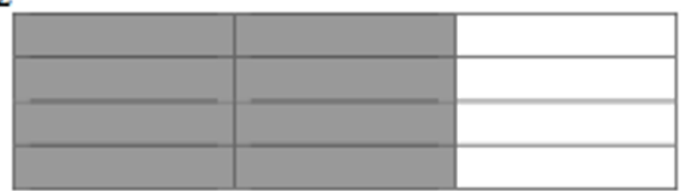

Step 3

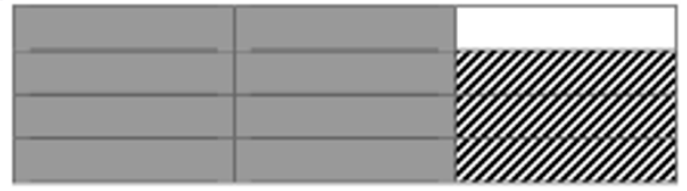

Figure 5 Betty's multi-step representation of adding fractions.

answering her questions in lines $558,559,561$, and 556, and listening to her commands in lines 558, 559, 561, and 563. Similar instances were observed in Whole Group Sharing in the classroom, as noted above.

In the episode, there is also a proposal for an alternative way to solve the problem, a value instilled in the course. Laura initiates a line of questioning about the meaning of quantities ("How many twelfths fit into four?"). Laura's line of questioning is aligned with the value about mathematical meanings espoused in the course. In line 569 Betty herself says that there is more than one way to solve the problem, in response to Laura's questioning. However, it seems that although the value is intoned, it is Betty's step-by-step procedure, which could be considered the more "traditional," teacher-centered ([Veel, 1999]), Laura's questioning line is not take up.

Betty seems to have a full range of semiotic resources at her disposal. She questions her "pupils," and uses commands extended over several speaking turns to present her approach. She uses visual and symbolic representation to build an argument and convey meanings. Meanwhile Laura's line of questioning is only a single turn, and she does not make use of all of the semiotic resources that Betty does. She also re-positions Betty as the "teacher," asking for her validation (line 568).

Laura's hesitance is in keeping with how she approached the course. She was ambivalent about Small Group Sharing, stating that she needed to know "the" answer before sharing and did not allude to the idea that different answers are possible. In the classroom, English monolingual space, Laura often did not use the multiple opportunities to share, and often kept to herself. However, as the excerpt shows here, she also re-voiced the value that mathematics is about meanings, i.e., attending to meaning of quantities, reference points over rote memorization of steps. However, in study sessions Laura begins to show some confidence. In these sessions, Laura was an active participant, and demonstrated an understanding of mathematical meanings, as the excerpt shows. 


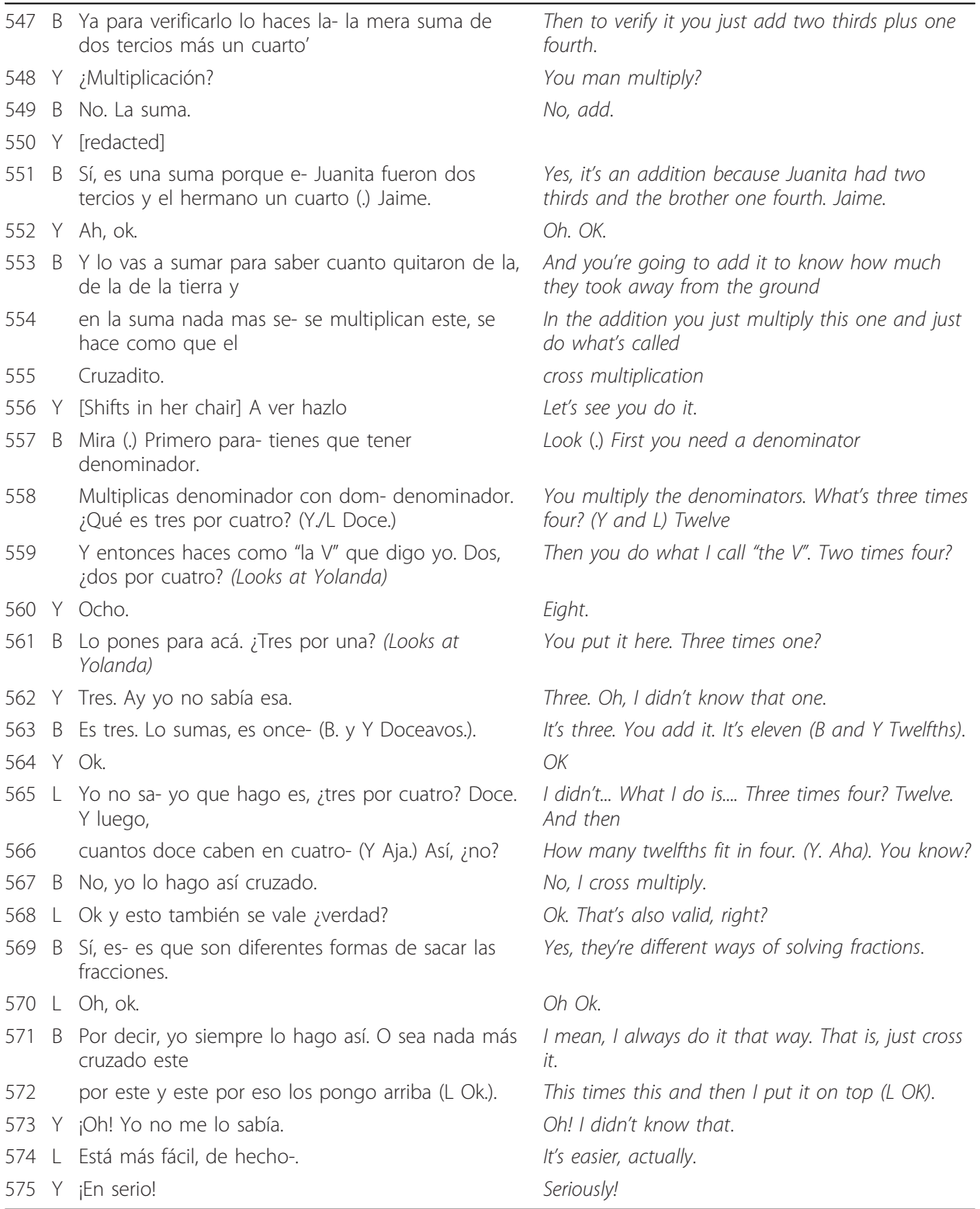

In study sessions, participants use multimodal mathematical discourse to present solutions, similar to the participant frameworks used in the classroom. However, whereas the classroom is mainly an English language space, study sessions are multimodal, bilingual spaces. In study sessions, multiple ways of representing mathematics, oral and spoken modes interact with different student's voices. In this space, values about the diversity of opinions are voiced, and students continue to voice it-although they do not quite practice it as in the classroom. Also in this space, a student like Laura is able to share with peers in ways that she did not in the classroom. In the same way, Betty is able to draw on the mathematical discourse to position herself using the authoritative voice of the teacher. 


\section{Discussion and implications}

In sum, in the mathematics classroom, students were socialized into mathematics discourse through the vehicle of participation structures that cycled around problem posing and solving. As [Sfard (2002)] notes, two crucial factors to socialize students into mathematical discourse are gaining access to meta-discursive rules and using its mediating tools. By participating in these structures, students gain access to rules of participation with others and making meaning in a discourse community. In addition, multimodality mediated interaction at every turn, as students participated in literacy events in which both speech and writing intermingled. Although neither multimodality nor explicit rules about how to participate in these structures were ever explicitly mentioned, the professor guided students to organize into different participation configurations. By participating in these structures, students interacted with their small group, with the professor and with the whole class. Students used a variety of semiotic resources to make meaning, including visual and symbolic representation to mediate verbalized presentation of solutions in English. Moreover, participants' interactions in study sessions outside the classroom revolved around presenting solutions to mathematical problems. In study sessions, participants used multimodality and biliteracy to engage with one another while at the same time forging an incipient identity as bilingual/biliterate teachers.

This study shows participants across situational contexts, interacting with a variety of interlocutors, and using multiple modalities across languages. In the college mathematics classrooms, discussion revolved around mathematical problems. Discussion in English around problems cycled through participant structures in which written mathematical representations mediated interaction. The literate discourse of mathematics relied on symbolic mediation ([Sfard, 2008]), and classroom oral English discussion was mediated by written mathematical representations (students wrote on notebooks or the board and the professor wrote on the board and on handouts). Thus, students are socialized multimodally, including through oral English discussions. Furthermore, the study also shows how values about mathematics education (cooperation, diversity of solutions, mathematics is meaningful) were intoned frequently.

Outside the classroom, in study sessions, these values as well as the use of multimodality were also observed among participants, in which participants were observed interacting with other bilinguals. The study session was a space which allowed students to position themselves as knowledgeable, authoritative and successful before her peers in their first language. Study sessions became for a student like Betty a space that allowed an opportunity to deploy her "multilingual, multimodal (bi)literacy practices toward the construction and transformation of [her] transnational identities and social relations" ([Hornberger, 2007], p. 4). As a borderland student, Betty constructs a nascent teacher identity that draws on her multiple experiences. She draws from her socialization in the classroom in English but also from her experiences substituting mathematics classes in Mexico and tutoring in Spanish. For instance, in an interview Betty noted that she was experienced in explaining mathematics concepts in Spanish, and got more practice explaining to others in the class. Solamente en las clases es cuando he practicado explicar como un problema en inglés porque por decir en, en lo que he sido de voluntaria siempre ha sido en español. Siempre ha sido como que elsiempre he enseñado en- no siempre las veces que he enseñado la mayoría de las veces 
ha sido en español porque he ayudado a alguien. (It's only in my classes where I have practiced explaining a problem in English because every time I've volunteered it has been in Spanish. That's always been the- I've always taught, I mean, every time I have taught it has been mostly in Spanish when I have helped someone.) Thus, Betty locates tutoring experiences in Spanish alongside classroom experiences in English to develop the ability to explain mathematical concepts. Her development of mathematical discourse is linked to multiple communities, which in her case cross national boundaries [Jiménez et al. 2009].

For students like Betty, Laura and Yolanda, opening possibilities toward transforming formal classrooms into borderland or transnational spaces-in which more than one language is spoken-might be verybeneficial. As they develop mathematical discourse, they can mediate their talk by visual and symbolic representations to construct meanings in two oral languages. This opens up possibilities for them to use translanguaging using all semiotic resources at their disposal. As García and Sylvan [(García 2011)] note, translanguaging includes a myriad of practices across languages and modalities, such as code-switching and translation. Permitting and even encouraging students like them to make meaning in both languages, such as during Small Group Sharing, could potentially be beneficial for their development of mathematics discourse. Once the meaning is communicated in the first language, aided by accurate symbolic and visual representation, it can be communicated in the second language, such as in Whole Group Sharing, where there is a change in audience. Participants in this study employed this strategy when they met, discussing their homework in Spanish and writing it in English. Once the mathematical meaning is clear to them in Spanish, writing it in their second language was more achievable. Offering opportunities to construct meaning using whatever semiotic resources are available to a student may help "quiet" students the chance to participate in Small Group Sharing and even in Whole Group Sharing. When students are able to draw on distinct points along the continua, they are able to develop and draw on their biliterate resources more effectively ([Hornberger \& Skilton-Sylvester, 2003]). The clearest example of this is Laura, who remained quiet during Small Group Sharing sessions in the classroom, but in study sessions was open, prepared, and eager to participate in Spanish.

For future teachers like Yolanda, Betty, and Laura, it might also be necessary to be explicit about making meaning across modalities. A critical aspect of scaffolding understanding is drawing a learner's attention to aspects of how meaning is constructed in specialized discourse; in this case, to the ways in which mathematical knowledge is constructed ([Schleppegrell, 2007,Lemke, 2003,O'Halloran, 2005]). In the classroom, visual and symbolic representations, which were ever present, were explicitly discussed only when a student made an error, such as when students represented a fraction visually and the fractions were of different sizes or when the equal sign was used as a placeholder rather than to mean both sides are equal. Thus, the importance of making meaning through multiple modalities might be, in some cases, a hidden aspect of preparing future teachers.

\section{Conclusions}

In conclusion, further research on ways that multimodality and bi/multilingualism can be a benefit for mathematics learning is needed. This research should consider 
gathering data of language use across multiple contexts, such as in learner's homes and communities ([Turner, et al., 2011]).

\section{Methods}

\section{Data collection}

During one semester, I conducted participant-observation in the class, and sat in a small group in to which two participants had been assigned. Students in the small group were aware that I was observing the class as a researcher interested in mathematics education. I attended $70 \%$ of all class meetings, most of the time observing how classroom activities unfolded and taking field notes.

In addition, participants conducted small group study sessions outside of class. They conducted study sessions as part of their participation in the research study. Sessions were conducted in a library group study room to work on mathematics assignments. Their interaction was video recorded and transcribed. Participants set the agenda for each study session, and chose the language to be used during the session.

In addition, I conducted informal interviews with the three main participants. The purpose of the interviews was to learn about participants' perceptions about the class, especially their perspective on the writing requirements. All interviews were recorded and transcribed professionally. A first round of interviews took place during the semester in which the participant-observation took place. Follow-up interviews were also conducted five months after class ended. In sum, data sources include a) field notes, b) interview transcripts, and c) study session transcripts.

\section{Data analysis}

The unit of analysis is the literacy event [(Heath, 1982)], which is an activity in which writing has a central role. The concept of literacy event allows coding of events in terms of the role mathematical writing plays in participants' biliterate development of the discourse of mathematics. Writing in this study includes any of the resources to make meaning in writing, including visual representation, symbolism and natural language. Data were coded to identify events in which mathematical writing played a central role. Event boundaries were signaled discursively by markers including "OK, let's begin," or "now, let's see," usually spoken by the professor. In literacy events, writing play a central, visible role with speakers positioning texts to be visible by all.

\footnotetext{
Acknowledgements

A University Research Initiative Grant funded by the State of Texas under the special Research Enhancement program made this research possible.
}

Authors' contributions

$A E$ is the sole author of this paper. He designed the study, collected and analyzed data, and wrote the manuscript.

Competing interests

The author declares that they have no competing interests.

Received: 14 November 2011 Accepted: 1 March 2012 Published: 1 March 2012

References

Acosta-Iriqui, J, M Civil, J Díez-Palomar, ME Marshall, and B Quintos-Alonso. 2011. Conversations around mathematics education with Latino parents in two borderland communities: the influence of two contrasting language policies. In Latinos/as and mathematics education: Research on learning and teaching in classrooms and communities,ed. Téllez K, Moschkovich J, Civil M. . Charlotte, NC: Information Age Publishing. 
Barwell, R. 2009. Mathematical word problems and bilingual learners in England. In Multilingualism and mathematics classrooms: global perspectives,ed. Barwell R. . Tonawanda, NY: Multilingual Matters.

Bunch, G. 2009. "Going up there": Challenges and opportunities for language minority students during a mainstream classroom speech event. Linguistics and Education 20: 81-108, doi:10.1016/.jlinged.2009.04.001. doi:10.1016/j. linged.2009.04.001.

Chval, KB, and LL Khisty. 2009. Bilingual Latino students, writing and mathematics: A case study of successful teaching and learning. In Multilingualism and mathematics classrooms: global perspectives,ed. Barwell R. . Clevedon UK: Multilingual Matters.

Duff, PA. 2007. Problematising academic discourse socialisation. In Learning discourses and the discourses of learning,ed. Marriot H, Moore T and Spence-Brown R. . Melbourne, Australia: Monash University e-Press/University of Sydney Press. 1.1-1.18.

Duff, PA. 2010. Language socialization into academic discourse communities. Annual Review of Applied Linguistics 30: 169-192.

Eggins, S. 2004. An introduction to systemic functional linguistics. 2 edition. New York: Continuum.

Esquinca, A. 2011. Bilingual college writers' collaborative writing of word problems. Linguistics and Education 22(2): 150-167, doi: 10.1016/j.linged.2010.12.006. doi:10.1016/j.linged.2010.12.006.

García, O, L Bartlett, and J Kleifgen. 2007. From biliteracy to pluriliteracies. In Handbook of applied linguistics on multilingual communication, ed. Auer P and Wei L. 207-228. New York: Mouton de Gruyter.

García, O. 2009. Bilingual education in the 21st century: a global perspective. Malden, MA: Wiley-Blackwell.

García, O. 2011. Pedagogies and practices in multilingual classrooms: singularities in pluralities. The Modern Language Journal 95(iii): 385-400, doi: 10.1111/j.1540-4781.2011.01208.x.

Gee, JP. 1996. Social linguistics and social literacies: ideology in discourses. New York: Routledge Falmer, 2.

Gee, JP. 2005. Language in the science classroom: academic social languages as the heart of school-based literacy. In Establishing scientific classroom discourse communities: multiple voices of teaching and learning in research, ed. Yerrick RW and Roth W-M. 19-37. Mahway, NJ: Lawrence Erlbaum Associates.

Gutiérez, K, T Sengupta-Irving, and J Dieckmann. 2010. Developing a mathematical vision: mathematics as a discursive and embodied practice. In language and mathematics education: multiple perspectives and directions for research,ed. Moschkovich J. . Charlotte, NC: Information Age Publishing.

Grosjean, F. 2008. Studying bilingualsOxford, UK: Oxford University Press.

Heath, SB. 1982. Protean shapes in literacy events: ever-shifting oral and literate traditions. In spoken and written language: exploring orality and literacy, ed. Tannen D. 91-118. Norwood, NJ: Ablex.

Halliday, MAK. 1978. Language as social semiotic: the social interpretation of language and meaningBaltimore, MD: Edward Arnold.

Halliday, MAK, and C Matthiessen. 2004. An introduction to functional grammar. London: Arnold, 3.

Hornberger, N. 1990. Creating successful learning contexts for bilingual literacy. Teachers College Record 92(2): 212-229.

Hornberger, N. 2007. Biliteracy, transnationalism, multimodality, and identity: Trajectories across time and space. Linguistics and Education 8(3-4): 325-334.

Hornberger, N, and E Skilton-Sylvester. 2003. Revisiting the continua of biliteracy: International and critical perspectives. Language and Education 14(2): 96-122.

Jiménez, R, P Smith, and BL Teague. 2009. Transnational and community literacies for teachers. Journal of Adolescent \& Adult Literacy 53(1): 16-26. doi:10.1598/JAAL.53.1.2.

Kress, G. 2010. Multimodality: A social semiotic approach to contemporary communication. New York: Routledge.

Lemke, JL. 1990. Talking science: Language, learning, and values. Norwood, NJ: Ablex Publishing Corporation.

Lemke, JL. 2003. Mathematics in the middle: Measure, picture, gesture, sign and word. In Educational perspectives on mathematics as semiosis: from thinking to interpreting to knowing,ed. Anderson M, Sáenz-Ludlow A, Zellweger S, Cifarelli W. . Legas: Ottawa, Ontario.

Martin-Jones, M. Bilingualism, education and the regulation of access to language resources. In Bilingualism: A social approach,ed. Heller M. . New York: Palgrave Macmillan.

Morales, HJ, E Vomvoridi-Ivanovic, and LL Khisty. 2011. A case study of multigenerational mathematics participation in an after-school setting: capitalizing on Latinas/os funds of knowledge. In Latinos/as and mathematics education: research on learning and teaching in classrooms and communities,ed. Téllez K, Moschkovich J, Civil M. . Charlotte, NC: Information Age Publishing.

Morgan, C. 1998. Writing mathematically: The discourse of investigation. London, UK: Falmer Press.

Moschkovich, J. 2002. A situated and sociocultural perspective on bilingual mathematics learners. Mathematics Thinking and Learning 4(2/3): 189-212.

Moschkovich, J. 2007. Bilingual mathematics learners: How views of language, bilingual learners, and mathematical communication impact instruction. In Diversity, equity, and access to mathematical ideas,ed. Nassir N and Cobb P. . NY: Teachers College Press.

Moschkovich, J. 2010. Language and mathematics education: Multiple perspectives and directions for research. Charlotte, NC: Information Age Publishing.

Ochs, E. 1988. Culture and language development: Language acquisition and language socialization in a Samoan village. Cambridge: Cambridge University Press.

Ochs, E, and BB Schieffelin. 2008. Language socialization: An historical overview. In Encyclopedia of language and education. Volume 8.. Second edition. ed. Duff P and Hornberger N. 3-16. New York: Springer. language socialization.

O'Halloran, KL. 2005. Mathematical discourse: Language, symbolism and visual images. New York: Continuum.

O'Rode, N. 2011. Latino/a students' understanding of equivalence: Use of two standards-based curricula in eight-grade algebra. In Latinos/as and mathematics education: Research on learning and teaching in classrooms and communities, ed. Téllez K, Moschkovich J, Civil M. . Charlotte, NC: Information Age Publishing.

Prediger, S. 2005. Diversity as a chance in mathematics classrooms. International Journal for Mathematics Teaching and Learning 1-8.

Schieffelin, B. 1990. The give and take of everyday life:language socialization of Kaluli Children. NY: Cambridge University Press. 
Schleppegrell, M. 2007. The linguistic challenges of mathematics teaching and learning: A research review. Reading \& Writing Quarterly 23: 139-159. doi:10.1080/10573560601158461.

Schleppegrell, M. 2010. Language in mathematics teaching and learning: A research review. In Language and mathematics education: multiple perspectives and directions for research,ed. Moschkovich J. . Charlotte, NC: Information Age Publishing.

Setati, M, J Adler, Y Reed, and A Bapoo. 2002. Incomplete journeys: Code-switching and other language practices in mathematics, science and English language classrooms in South Africa. Language and Education 16(2): 2-22.

Setati, M. 2005. Teaching mathematics in a primary multilingual classroom. J Res Math Educ 36(5): 447-466.

Sfard, A. 2002. Learning mathematics as developing a discourse. Paper presented at the 21st Conference of PME-NA, Columbus, $\mathrm{OH}$.

Sfard, A. 2008. Thinking as communicating: Human development, the growth of discourses, and mathematizing. Cambridge, UK: Cambridge University Press.

Solomon, Y. 2009. Mathematics literacy: Developing identities of inclusion. New York: Routledge.

Turner, EE, MV Gutiérez, and J Díez-Palomar. 2011. Latino/a bilingual elementary students pose and investigate problems grounded in community settings. In Latinos/as and mathematics education: Research on learning and teaching in classrooms and communities,ed. Téllez K, Moschkovich J and Civil M. . Charlotte, NC: Information Age Publishing.

Valdés, G, H Brooks, and C Chávez. 2003. Bilinguals and bilingualism. In Expanding definitions of giftedness: the case of young interpreters form immigrant communities, ed. Valdes G and Mahwah NJ. 25-62. Lawrence Erlbaum Associates.

Veel, R. 1999. Language, knowledge and authority in school mathematics. In Pedagogy and the shaping of consciousness, ed. Christie F. 185-216. London: Continuum.

Vygotsky, LS. 1978. Mind in society. Cambridge, MA: Harvard University Press.

Zahner, W, and J Moschkovich. 2011. Bilingual students using two languages during peer mathematics discussions: ¿Qué significa? Estudiantes bilingües usando dos idiomas en sus discusiones matemáticas: What does it mean? In Latinos/as and mathematics education: research on learning and teaching in classrooms and communities,ed. Téllez $\mathrm{K}$, Moschkovich J and Civil M. . Charlotte, NC: Information Age Publishing.

doi:10.1186/2191-5059-2-4

Cite this article as: Esquinca: Socializing pre-service teachers into mathematical discourse: the interplay between biliteracy and multimodality. Multilingual Education 2012 2:4.

\section{Submit your manuscript to a SpringerOpen ${ }^{\odot}$ journal and benefit from:}

- Convenient online submission

- Rigorous peer review

- Immediate publication on acceptance

- Open access: articles freely available online

- High visibility within the field

- Retaining the copyright to your article

Submit your next manuscript at $\gg$ springeropen.com 